\title{
RETROSPECTIVE MODIFICATION OF ALIMONY DECREES: A PROPOSED INNOVATION FOR ILLINOIS
}

Courts in Illinois are given statutory power to make "such alterations in the allowance of alimony ... as shall appear reasonable and proper." Under this statute, either party to an alimony decree may move for reconsideration of the original order and, upon proof of changed circumstances, may in the court's discretion obtain modification of the decree so as to increase, reduce, ot terminate future payments. Yet the rule that alimony installments once accrued are not subject to retrospective change has been established since 1896. ${ }^{2}$ The Illinois rule as to the finality of accrued alimony accords with the weight of authority in the several states. The majority of states have statutes which allow modification of alimony decrees where circumstances have changed subsequent to the original ascertainment of equities, but which do not deal expressly with the problem of installments already accrued. ${ }^{3} \mathrm{~A}$ few states have legislation expressly limiting the power of modification to prospective operation. ${ }^{4}$ The New York statute, however, provides that the authority to modify shall extend to installments accrued prior to application for alteration, but specifies that once judgment for arrears is entered it is final. ${ }^{5}$

${ }^{1}$ III. Rev. Stat. (1953) c. 40, § 19.

${ }^{2}$ Craig v. Craig, 163 Ill. 176, 45 N.E. 153 (1896); Helkelkia v. Sonzinski, 223 III. App. 30 (1921); Igney v. Igney, 303 IIl. App. 563, 25 N.E. 2d 608 (1940); Bush v. Bush, 316 III. App. 295, 44 N.E. $2 d 767$ (1942); Shuff v. Fulte, 344 IIl. App. 157, 100 N.E. 2d 502 (1951).

${ }^{3}$ These statutes may be grouped roughly as follows: (a) Those which confer upon the courts a power from time to time to make "proper" alterations [e.g., Ark. Stat. Ann. (1948) § 34-1213; Mo. Stat. Ann. (Vernon, 1952) \& 452.070], to "amend, revise and alter" [e.g., Ariz. Code Ann. (1939) § 27-811], or "modify" [e.g., Idaho Code (1948) §32-706; N. D. Rev. Code (1944) § 14-0524; S. D. Code (1939) \$ 14.0726]; and (b) those which provide that the court "may make any decree . . . which it might have made in the original suit" [e.g., Mass. L. Ann. (1933) c. 208, \$37]. The wording of the former group is less definitive and has not been uniformly interpreted, but the predominant view is that such statutes operate only prospectively; statutes of type (b) have more often been held to permit retroactive modification. For other variations see Alimony-Retrospective Modification, 6 A.L.R. 2d 1277, 1288 et seq. (1949).

' E.g., Nev. Comp. L. (Supp., 1943-49) \$9474.01 ("the provisions of this act shall not preclude the parties from entering into a stipulation as to accrued installments prior to the time a motion for modification is filed"); Va. Code (1950) \$20-109.

${ }^{5}$ N.Y. Civil Practice Act (Gilbert-Bliss, Supp., 1954) §1170: ". . . Where an action for divorce or separation is brought by ... [the] wife, [the court must give such directions as justice requires] for the support of the plaintiff. The court, by order, upon the application of either party to the action ... after due notice to the other, to be given in such manner as the court shall prescribe, at any time after final judgment, may annul, vary or modify such directions. . . . Subject to the provisions of section eleven hundred seventy-one-b the authority granted by this section shall extend to unpaid sums or installments accrued prior to the application as well as to sums or installments to become due thereafter." Ibid.s \$1171-b: "[T]he court in its discretion may make an order directing the entry of judgment for the amount of ... arrears, or for such part thereof as justice requires having regard to the circumstances of the respective parties. ... The application for such order shall 
The facts in a recent case suggest the hardship that may arise under the present Illinois rule. Plaintiff in Stewart $v$. Stewart ${ }^{6}$ had obtained an Illinois circuit-court decree awarding her a divorce and alimony of $\$ 100$ per month. Her ex-spouse later remarried; some time thereafter he was declared an incompetent and institutionalized. His second wife, as conservator of his estate, utilized the available funds for her own support and failed to make further alimony payments on behalf of her husband. In 1949 plaintiff filed suit to enforce payment of four years' arrearages, naming as one of the defendants the second wife individually and as conservator. Evidence was offered to show that the estate of the incompetent husband was small; that after his commitment to the state hospital he had no income other than the monthly payments received on a land contract (which just equalled the amount he was obligated to pay under the alimony decree); and that his second wife conducted a rooming house in order to supplement this income. The appellate court, affirming a finding for the plaintiff, said: "In view of the changed conditions appearing in this case, a petition to alter the alimony provisions, if presented, might have been allowed. Nevertheless, the past due alimony is vested and cannot be taken away."

Illinois law might profitably be changed to permit relief for defendants in such unfortunate circumstances as existed in the Stewart case. Before considering any change, however, attention will be given to the various equitable considerations underlying the conflicting rules-viz., that of the Illinois courts under which accrued installments of alimony are unalterable, and that of a minority of states which allow retrospective modification. Should such a power be established, the finality of Illinois alimony decrees in terms of the full faith and credit clause might be impaired, thereby creating the problem of obtaining enforcement of such decrees in sister states. Special attention will be given this problem before considering new legislation.

\section{I}

There are important equitable considerations supporting the view that retrospective modification of alimony should not be permitted. A wife dependent for her support upon alimony should be protected in her reasonable reliance upon a right to enforce an obligation which, it must be assumed, was justly imposed under circumstances then existing. If she has obtained credit

be upon such notice to the husband or other person as the court may direct ... provided that when a judgment for such arrears or any part thereof shall have been entered pursuant to this section, such judgment shall thereafter not be subject to modification under the discretionary power granted by this section. ..."

The statute was amended to this effect in 1948 to resolve conflicting views of the various departments of the Appellate Division. The question had not reached the Court of Appeals.

- IIl. App. -, 117 N.E. 2d 579 (1954).

I Ibid., at,- 581 . 
in the belief that past-due alimony represents a fund rightly hers, she ought not be prejudiced by her husband's failure, upon a change in circumstances, to make timely motion for modification. Even where credit is not involved, there are psychological elements of reliance worthy of protection; her personal plans should not be subject to defeasance without grave reason. Further, if accruals were not final, the husband might deliberately default in the hope that if he were called into court he would be let off lightly; whereas the wife would tend to litigate each installment which was not promptly paid, when she might otherwise give the husband a period of grace beneficial to both parties.

On the other hand, it must be remembered that alimony represents an obligation peculiar in its nature. It is not a debt, but has its origin in the continuing.obligation of a husband to support his wife, which is normally not extinguished by divorce. During marriage, the standard of his obligation fluctuates with his fortunes; there is no reason for freezing the standard as of the date the marriage is dissolved.

To deny a court of chancery [the power to cancel or reduce arrears] prevents the rectification of an obligation which would not have been created had the chancellor been able to anticipate the later faculties of the husband, and defeats the rule that the maintenance afforded the separated wife through alimony is not to be greater than what she would have enjoyed in cohabitation. ${ }^{8}$

The most typical case in which a retroactive power could be exercised to relieve hardship is that in which the husband fails to make timely motion for reconsideration in reliance upon the wife's prolonged failure to protest nonpayment. From his point of view such reliance may be a reasonable alternative to the expense attendant upon a judicial rehearing. Or his omission to move may be due to ignorance; "not all divorced husbands are lawyers." $\mathrm{He}$ may not have sufficient funds to engage counsel. ${ }^{10}$ Or he may delay in conscientious expectation that he will ultimately be able to satisfy accrued installments. In such cases it may be overly harsh to require the husband to suffer the consequences of the impossibility of accurate prediction. At least where the wife has not been prejudiced by his failure to take the prescribed procedural steps, there is little justification for inflicting so disproportionate a penalty.

The rule permitting retroactive modification seems the more apt to achieve substantial justice, provided that the power is exercised only after careful consideration of the wife's circumstances. However, there is still one strong argument that militates against instituting such a power: A wife attempting to compel payment of alimony in a state other than that which rendered the original decree may be deprived of effective remedy if the judgment falls short

\footnotetext{
${ }^{8}$ Winkel v. Winkel, 178 Md. 489, 500, 15 A. 2d 914, 919 (1940).

${ }^{9}$ Washington, C.J., dissenting in Kephart v. Kephart, 193 F. 2d 677, 690 (App. D.C., 1951), cert. denied 342 U.S. 944 (1952).

${ }^{10}$ Conklin v. Conklin, 223 Minn. 449, 27 N.W. 2d 275 (1947).
} 
of that degree of finality necessary to entitle it to full faith and credit under the Constitution. Legislation for the protection of husbands might not be justified at such a cost. Consequently, the law of out-of-state enforcement merits consideration in some detail.

\section{II}

Although a state may, of its own volition, enforce the terms of an alimony decree rendered in another state, it is obviously desirable that the beneficiary of the decree be able to compel enforcement under the full faith and credit clause. In an early case, ${ }^{11}$ suit was brought in a federal court in Wisconsin for installments accrued under a New York decree. In affirming enforcement, the Supreme Court said:

[A] judgment or decree [for divorce and alimony], rendered in any State of the United States, the court having jurisdiction, will be carried into judgment in any other State, to have there the same binding force that it has in the State in which it was originally given. For such a purpose, both the equity courts of the United States and the same courts of the States have jurisdiction. ${ }^{12}$

Some years later, in Lynde v. Lynde, ${ }^{13}$ the Court affirmed a decision of the New York Court of Appeals which had allowed the wife to recover an amount found due by a New Jersey court but denied enforcement of installments accrued since the date of the New Jersey decree. The Court said: "The provision of the payment for [sic] alimony in the future was subject to the discretion of the Court of Chancery of New Jersey, which might at any time alter it, and was not a final judgment for a fixed sum."14

These two earlier cases were cited by opposing counsel in Sistare v. Sistare $^{15}$ and inspired the Court to formulate a general rule resolving any conflict which may have existed between them:

[G]enerally speaking, where a decree is rendered for alimony and is made payable in future installments the right to such installments becomes absolute and vested upon becoming due, and is therefore protected by the full faith and credit clause, provided no modification of the decree has been made prior to the maturity of the installments.... [T] his general rule, however, does not obtain where by the law of the State in which a judgment for future alimony is rendered the right to demand and receive such future alimony is discretionary with the court which rendered the decree, to such an extent that no absolute or vested right attaches to receive the installments ordered by the decree to be paid, even although no application to annul or modify the decree in respect to alimony had been made prior to the installments becoming due. ${ }^{18}$

11 Barber v. Barber, 21 How. (U.S.) 582 (1858).

${ }^{12}$ Ibid., at 591. The Court did not mention the full faith and credit clause, and the statement quoted is probably dictum.

23181 U.S. 183 (1901).

16 Ibid, at 187 .

${ }^{15} 218$ U.S. 1 (1910).

${ }^{10}$ Ibid., at 16-17. 
The rule and qualification thereof, known as "the Sistare doctrine," have so influenced the state courts that the majority have refused to enforce out-ofstate decrees not strictly entitled to full faith and credit. Apparently most states are unaware of the possibility of voluntary enforcement or unwilling to avail themselves of it. ${ }^{17}$ Of courts which have discussed the subject, some have refused enforcement because of reluctance to exercise authority which might subsequently prove to be in conflict with that of the rendering state. ${ }^{18}$

The Sistare doctrine has been subjected to indirect criticism in recent cases. In Barber v. Barber, ${ }^{19}$ it was assumed but not decided that a modifiable $j u d g$ ment for arrears would also lack that degree of finality necessary under the full faith and credit clause; but Mr. Justice Jackson, concurring, disapproved the assumption and criticized the general requirement of finality. He pointed out that neither the full faith and credit clause nor the congressional legislation implementing it made reference to finality. ${ }^{20}$

Griffin v. Griffin ${ }^{21}$ involved a New York alimony decree; the wife, without notice to her husband, had had judgment docketed in New York for accrued

\footnotetext{
${ }^{17}$ E.g., the Alabama court in McAlister v. McAlister, 214 Ala. 345, 107 So. 843 (1926), was convinced that a condition placed upon the payment of alimony in a Louisiana decree operated to reserve an exclusive power in the Louisiana court to enforce its terms. The decree provided that defendant pay plaintiff $\$ 50$ per month "as long as said alimony is necessary." The court said: "[T] $]$ here was written upon the face of the order itself ... a clear restriction upon defendant's duty to pay in such sense as to deny the plaintiff any vested right in future accruing installments, and reserving to the rendering court exclusively the right and the power to ascertain the existence vel non of the contingency upon which they were to be paid." Ibid., at 347,845 .

As recently as 1948, voluntary enforcement was described as a "new proposition": "If the Supreme Court [in Griffin v. Griffin, 327 U.S. 220 (1946)] is . . . indicating this new proposition, that although the accrued alimony remains reducible in the original state, the same equities which would reduce it at home can reduce it abroad, and the action abroad may thus enforce the unfixed obligation-its decision unseats . . . much law hitherto thought well settled." State of New York Law Revision Commission, Report, Recommendations and Studies 269 (1948). As might be inferred, New York has consistently refused to enforce decrees not entitled to full faith and credit. Johnson v. Johnson, 196 Misc. 487, 92 N.Y.S. 2d 517 (S. Ct., 1949).

"On the whole the state courts have adhered rather closely to the federal doctrine enunciated in Sistare $v$. Sistare. They have not given effect to the F-1 decree unless required to do so by the full faith and credit clause." Jacobs, The Enforcement of Foreign Decrees for Alimony, 6 Law and Contemporary Problems 250, 263 (1939), and cases cited therein
} at $262 \mathrm{n} .71$.

${ }^{18}$ Comity-Enforcement of Alimony, 132 A.L.R. 1272 (1941), and cases cited therein.

${ }^{19} 323$ U.S. 77 (1944).

${ }^{20}$ Ibid., at 87. U.S. Const. Art. 4, § 1: "Full faith and credit shall be given in each State to the public acts, records, and judicial proceedings of every other State." The implementing legislation has been modified since the Barber case but without substantive change. It reads: "[The records and judicial proceedings of any court of any State] shall have the same full faith and credit in every court within the United States . . . as they have by law or usage in the courts of ... [the] State ... from which they are taken." 62 Stat. 947 (1948), 28 U.S.C.A. § 1738 (1950).

2327 U.S. 220 (1946). 
installments and recovered upon the judgment in the District of Columbia. The Supreme Court reversed, holding that the judgment was rendered without due process, since, without notice to the husband, it purported to terminate the power of retrospective modification which existed in New York. Where the requirements of due process are not observed, a judgment is not entitled to full faith and credit; nor may it be enforced by a sister state of her own volition. Justices Rutledge, Black and Frankfurter, dissenting, approved Justice Jackson's position in the Barber case that a modifiable judgment (as they conceived the New York judgment to be) should not be deprived of full faith and credit.22

The minority opinions in the Barber and Grifin cases indicate some dissatisfaction with the requirement of finality under the full faith and credit clause; and it may be that the issue to which legislative attention is here called will one day become academic. But at present the Sistare doctrine governs the behavior of the majority of state courts. It would seem wise, in drafting legislation, to meet this current problem, rather than simply to provide for a retroactive power of modification and hope for a future change in the law to protect those seeking out-of-state enforcement.

\section{III}

There are several possible legislative approaches to the problem of conferring a power of retrospective modification upon the Illinois courts, without impairing the enforceability of Illinois alimony decrees in other states:

(1) Legislation patterned after that of New York would effectively meet the requirements of the full faith and credit clause of the Constitution, but only at the expense of adding an additional procedural obstacle to enforcement. A New York wife endeavoring to compel payment must move for entry of judgment under the original decree; notice must again be given the husband; then, if she seeks enforcement in another state, another suit must be brought to recover on the now-final judgment. Nor is the notice requirement limited to cases in which full faith and credit is sought; under the holding in the Griffin case, entry of a judgment which terminates the power of retroactive modification violates due process if notice is not given to the adverse party. Such a judgment may not be enforced by a sister state even if she is willing to do so. In addition, the Fourteenth Amendment would prevent enforcement in the home state. The requirement that notice be given the husband before such a judgment is entered has special merit in light of the type of case for which the power of retroactive modification is most sorely needed-viz., that

${ }^{2 n} \mathrm{Mr}$. Justice Rutledge said: "The full faith and credit clause does not . . . require that a judgment, to be credited, must be endowed with absolute finality. It is enough, in my opinion, if the judgment is endowed by the law of its origin with finality sufficient to sustain the issuance and levy of execution, although the same law may afford an opportunity for setting aside or modifying it upon the making of a specified showing." Ibid., at 247. 
in which unpaid installments have accrued for a period of years. With the passage of time, it is unlikely that it will occur to the husband to take legal action unless he discovers that his wife is preparing to move. In such a situation, the wife should not be able to render the retroactive power inoperative by having judgment docketed without notice to her unsuspecting husband.

Under the New York statute, then, every past-due installment of alimony sought to be recovered must be readjudicated. This imposes a heavy burden on those wives who are financially unable to let installments accrue, and since the average award may not exceed court costs and counsel fees, the necessity for continuous litigation where the husband is uncoöperative may well defeat the purpose of alimony.

(2) Alternatively, the finality of accrued installments might be sufficiently preserved for sister-state enforcement by providing that the chancellor in his discretion may enjoin execution when justice so requires, just as he is universally empowered to do in event of fraud, payment, or want of jurisdiction. The availability of these traditional defenses is never held to deprive a judgment of the benefit of full faith and credit. By putting the new equitable ground for relief in the same category with these defenses and providing that they be raised in a suit independent of that brought on the judgment (thereby emphasizing their exceptional character), the judgment itself may retain sufficient finality to come within the full faith and credit clause-or at least sister states may be encouraged to enforce it. However, the efficacy of this technique is open to doubt. If the proposed legislation were drafted clearly enough to insure that Illinois courts would recognize and exercise the power conferred on them, it would be readily perceived by sister states that the power is one to which the Sistare doctrine would apply.

(3) A third and more novel approach would give qualified protection to both husband and wife and yet meet the full faith and credit problem squarely, by setting up a period of "temporary finality." Such a result might be accomplished by amending the Illinois divorce act to provide that as each installment of alimony accrued, it would ripen into a final judgment for that amount, upon which execution would issue at any time within a specified period, e.g., one year. ${ }^{23}$ After the expiration of that year, enforcement could be had only after a petition therefor was presented by the wife ${ }^{24}$ and notice given the hus-

${ }^{23}$ To protect the wife when suing in another state where execution would not issue automatically as in Illinois, it would be advisable to provide that if she had instituted enforcement proceedings within the year but had not yet obtained satisfaction because of court delays, the judgment would retain finality for whatever additional time was required for judicial disposition of her claim. Such an extension of the period of finality ought to be binding upon Illinois courts, as well as upon those of the state in which suit is brought, in order to avoid the conflict of authority which would arise should the husband obtain modification in Illinois while the wife awaited her out-of-state judgment.

${ }^{24}$ Or husband, since Illinois law provides that either may be the beneficiary of an alimony decree [Ill. Rev. Stat. (1953) c. 40, § 19]. 
band, who might then introduce proof of changed circumstances. The court, in its discretion, might then modify or cancel arrearages if justice so required in light of the circumstances of both parties.

Under such a provision, a husband could not be taken unaware by enforcement of arrears of more than a year; a wife, in order to escape the possibility of further contest, would need only to obtain execution ${ }^{25}$ within that year. This does not seem an excessive standard of diligence to impose, inasmuch as a wife honestly in need of alimony for support in any case would be compelled to take reasonably prompt action.

Of the possible solutions considered, the third appears to deal most effectively with the problems discussed in this comment. It is believed that most cases of hardship could thus be relieved, and that a judgment under such a provision would be entitled to full faith and credit for that period in which the home state placed no equitable condition upon its enforcement. It is therefore suggested that the Illinois legislature give serious consideration to amending its divorce act along these lines.

${ }^{2}$ Or institute suit in another state.

\section{PRE-FUING DELAYS IN ILLINOIS MARITAL ACTIONS- THEIR CONSTITUTIONALITY AND UTILITY}

The most recent attempt ${ }^{1}$ of the Illinois legislature to enact a formalized reconciliation procedure to avert broken marriages was declared unconstitutional in People ex rel. Christiansen v. Connell. ${ }^{2}$ The statute required any party desiring to commence an action of annulment, separate maintenance, or divorce to file, not less than sixty days nor more than one year prior to the filing of a complaint, a statement of intent to bring action. The trial court was given discretionary power to "waive" compliance with the time requirement. During the "cooling-off" period the judge could invite the voluntary attendance of the prospective litigants at a reconciliation conference, but was not empowered to issue binding orders. ${ }^{3}$

1 The legislature had twice before attempted without success to accomplish some of the objectives of the statute here at issue. Section 105 of Chapter 37 of the Ilinois Statutes (SmithHurd, 1947), which set up a "divorce division" in judicial circuits of 500,000 or more, was held repugnant to Article IV, Section 22, of the Illinois Constitution in Hunt v. Cook County, 398 III. 412, 76 N.E. 2 d 48 (1947). See Unconstitutionality of Illinois Divorce Act, 15 Univ. Chi. L. Rev. 770 (1948). To obviate the objections of the Hunt decision the Illinois legislature passed the Domestic Relations Act of 1949 [11]. Rev. Stat. (1949) c. 37, \$ 105.20]. This legislation was held unconstitutional in Bernat v. Bicek, 405 Ill. 510, 91 N.E. 2d 588 (1950). The various grounds of the Bernat decision are discussed in Legislative Progress and Judicial Reluctance in Illinois Divorce Reform, 18 Univ. Chi. L. Rev. 342 (1951). Neither statute provided for a pre-filing delay.

22 III. 2d 332, 118 N.E. 2d 262 (1954).

${ }^{3}$ IIl. Rev. Stat. (1953) c. 40, $\$ 23$ : "Subject to the exceptions hereinafter provided, any person desiring to commence an action for divorce, separate maintenance or annulment of 